\title{
Does Cabergoline Help in Decreasing Chronic Pelvic Pain Due to Endometriosis Compared to Medroxyprogesterone Acetate? A Prospective Randomized Study
}

\author{
${ }^{1}$ Amit Kyal, ${ }^{2}$ Atri Pal, ${ }^{3}$ Aprateem Mukhopadhyay, ${ }^{4}$ Partha Mukhopadhyay
}

\begin{abstract}
Introduction: Endometriosis is a chronic debilitating disease which adversely affects the equality of life of the woman. The exact pathophysiology of the disease and cause of pain is not clearly understood and so confounds an attempt to select the most favourable clinical management. The study aims to assess the safety and efficacy of cabergoline with respect to medroxyprogesterone acetate in treatment of chronic pelvic pain (CPP) due to endometriosis.

Materials and methods: This study was conducted in Medical College, Kolkata from June 2015 to June 2016. Eighty patients of chronic pelvic pain due to endometriosis (diagnosed by USG and laparoscopy) were randomly assigned into two groups of 40 each receiving either medroxyprogesterone acetate (10 mg TDS) or cabergoline ( $0.5 \mathrm{mg}$ twice weekly) for 12 weeks. Response for pain was measured on a visual analog scale (VAS) of $0-10$ scale at the beginning of treatment and at intervals of 1, 3, 4 and 6 months.
\end{abstract}

Results: The study shows that the decrease in pain scores at various time points was statistically significant in both the groups. However, when the two groups were compared among themselves the reduction in VAS score at various time points were not statistically significant. Patients receiving medroxyprogesterone acetate had more side effects $(67.5 \%)$ compared to cabergoline $(47.5 \%)$. The most common side effect in medroxyprogesterone acetate group was amenorrhea $(25 \%)$ whereas, in the cabergoline group, it was nausea and vomiting $(45 \%)$.

Conclusion: Cabergoline and medroxyprogesterone acetate are equally effective in decreasing chronic pelvic pain due to endometriosis. However, due to lesser side effects and less frequent dosing, cabergoline has a better acceptance and compliance than medroxyprogesterone acetate. Thus cabergoline can be a better alternative to medroxyprogesterone acetate.

\footnotetext{
${ }^{1}$ Associate Professor, ${ }^{2,3}$ Postgraduate Trainee, ${ }^{4}$ Professor and Head of Department

1,2Department of Obstetrics and Gynecology, Medical College and Hospital, Kolkata, West Bengal, India

${ }^{3}$ Department of Radiodiagnosis, Medical College and Hospital, Kolkata, West Bengal, India

${ }^{4}$ Department of Obstetrics and Gynecology, Medical College and Hospital, Kolkata, West Bengal, India
}

Corresponding Author: Atri Pal, Postgraduate Trainee, Department of Obstetrics and Gynecology, Medical College and Hospital, Kolkata, West Bengal, India, Mobile: +918017033589, e-mail: alpha_pi@rediffmail.com
Keywords: Cabergoline, Chronic pelvic pain, Endometriosis, Medroxyprogesterone acetate.

How to cite this article: Kyal A, Pal A, Mukhopadhyay A, Mukhopadhyay P. Does Cabergoline Help in Decreasing Chronic Pelvic Pain Due to Endometriosis Compared to Medroxyprogesterone Acetate? A Prospective Randomized Study. J South Asian Feder Obst Gynae 2018;10(3):167-169.

Source of support: Nil

Conflict of interest: None

Date of recived: 03/04/2016

Date of acceptance: 15/05/2017

Date of Publication: December 2018

\section{INTRODUCTION}

Endometriosis is a chronic debilitating disease which adversely affects the quality of life of the woman. Prevalence at present is around $10 \% .{ }^{1}$ Endometriosis is a very common cause of $\mathrm{CPP}^{2}$ and is found in as much as 20 to $90 \%$ of the patients .

The exact pathophysiology of the disease and the cause of pain is not clearly understood and thus confounds an attempt to select the most favorable clinical management.

Neovascularization has a pivotal role in the development of endometriosis. ${ }^{3}$ Amongst the known angiogenic factors, Vascular endothelial growth factor (VEGF) has been found to as the most important regulator of normal angiogenesis and neovascularization. Increased VEGF is found in the endometriotic lesion and peritoneal fluid of patients with endometriosis. ${ }^{4,5}$

It has been found from recent studies that neurotransmitter dopamine inhibits VEGF induced angiogenesis at nontoxic doses. ${ }^{6}$

Dopamine and its agonists, such as cabergoline, promote VEGF receptor-2 endocytosis in endothelial cells, therefore VEGF-VEGFR-2 binding is prevented and neoangiogenesis is decreased. ${ }^{7}$ It has been found that daily treatment with cabergoline suppresses cell proliferation and VEGF mediated angiogenesis thereby helping in regression of endometriotic lesions. ${ }^{8}$ So cabergoline can be a novel drug for the treatment of chronic pelvic pain due to endometriosis.

Medroxyprogesterone acetate is a commonly used, cheap, easily available drug for treatment of endome- 
Table 1: Comparison of age (in years) between the two groups M-Medroxprogesterone acetate, $\mathrm{C}-$ Cabergoline

\begin{tabular}{lllllll}
\hline $\begin{array}{l}\text { Group } \\
\text { name }\end{array}$ & Mean & Median & S.D & Minimum & Maximum & Range \\
\hline M & $29.55^{*}$ & 28.0 & 3.038 & 26 & 37 & 11 \\
C & $29.65^{*}$ & 29.0 & 3.000 & 26 & 38 & 12 \\
\hline
\end{tabular}

triosis. The present research proposal is to systematically study the effect of cabergoline on chronic pelvic pain due to endometriosis in comparison with medroxyprogesterone acetate.

\section{MATERIALS AND METHODS}

The study was conducted in Department of Gynaecology and Obstetrics, Medical College, Kolkata from July 2015 to June 2016. It was a prospective comparative interventional study. 80 patients in the age group 25 to 40 years and suffering from chronic pelvic pain who were diagnosed with the help of USG and laparoscopy to suffer from endometriosis, were included in the study after institutional ethics approval and consent from the study subjects. Patients with abnormal LFT, renal impairment, heart disease, uncontrolled hypertension and diabetes mellitus were excluded. The patients were randomized and assigned into two groups (groups $\mathrm{M}$ and C) of 40 each. Group M received medroxyprogesterone acetate (10 $\mathrm{mg}$ TDS daily), and group $\mathrm{C}$ received cabergoline ( $0.5 \mathrm{mg}$ twice weekly) for 12 weeks. The response of the patient for pain was measured on a VAS of 0 to 10 at the begining of treatment and after that at 1,3, 4 and 6 months. Data collected were tabulated and analyzed as per standard statistical protocol. The $p$-value $\leq 0.05$ were considered significant.

\section{RESULTS}

Eighty patients with chronic pelvic pain due to endometriosis were randomly divided into two groups of 40 each. Group M received medroxyprogesterone acetate, and group C received cabergoline for 12 weeks respectively, and the VAS score was recorded at various time points.

Mean age of patients in group $\mathrm{M}$, and $\mathrm{C}$ were 29.55 and 29.65 respectively (Table 1 ). Applying the unpaired t-test no statistically significant difference was found between the two groups ( $p>0.05)$.

Table 3: Comparison of pain scores in the group receiving cabergoline $(\mathrm{C})$ across various time points

\begin{tabular}{llllll}
\hline & $\begin{array}{l}\text { VAS at } \\
\text { beginning }\end{array}$ & $\begin{array}{l}\text { VAS at } 1 \\
\text { month }\end{array}$ & $\begin{array}{l}\text { VAS } \\
\text { at 3 } \\
\text { month }\end{array}$ & $\begin{array}{l}\text { VAS } \\
\text { at } 4 \\
\text { month }\end{array}$ & $\begin{array}{l}\text { VAS at 6 } \\
\text { month }\end{array}$ \\
\hline Mean & 8.93 & 5.78 & 4.30 & 3.75 & 4.13 \\
Median & 9.00 & 6.00 & 4.50 & 4.00 & 4.0 \\
SD & 0.730 & 1.025 & 1.114 & 1.032 & 1.137 \\
Range & 2 & 4 & 4 & 4 & 4 \\
Minimum & 8 & 4 & 2 & 2 & 2 \\
Maximum & 10 & 8 & 6 & 6 & 6 \\
\hline
\end{tabular}

Table 2 : Comparison of pain score in group recieving

medroxprogesterone acetate across various time points

\begin{tabular}{llllll}
\hline & $\begin{array}{l}\text { VAS at } \\
\text { beginning }\end{array}$ & $\begin{array}{l}\text { VAS at } 1 \\
\text { month }\end{array}$ & $\begin{array}{l}\text { VAS at } 3 \\
\text { month }\end{array}$ & $\begin{array}{l}\text { VAS at } 4 \\
\text { month }\end{array}$ & $\begin{array}{l}\text { VAS at } 6 \\
\text { month }\end{array}$ \\
\hline Mean & $8.93^{*}$ & $6.33^{*}$ & $4.38^{*}$ & $3.53^{*}$ & $4.28^{*}$ \\
Median & 9.00 & 6.00 & 4.00 & 4.00 & 4.00 \\
S.D & 0.730 & 1.023 & 1.148 & .847 & 4.00 \\
Range & 2 & 4 & 4 & 3 & 1.240 \\
Minimum & 8 & 4 & 3 & 2 & 4 \\
Maximum & 10 & 8 & 7 & 5 & 2 \\
\hline
\end{tabular}

In our study, the mean VAS for Group $M$ at the beginning was 8.93 and at 1 month, 3 months, 4 months and 6 months were $6.33,4.38,3.53$, and 4.28 respectively. By applying ANOVA the decrease in the pain score was found to be statistically significant when compared to the VAS at the beginning $(\mathrm{p}<0.05)$. However, there was an increase in VAS score at 6 months when compared to that of 4 months (Table 2).

Mean VAS for group $C$ at the beginning was 8.93 and at 1, 3, 4, 6 months were 5.78, 4.30, 3.75, 4.13 respectively. By applying analysis of variance (ANOVA) the decrease in the VAS score was found to be statistically significant when compared to the VAS at the beginning $(p<0.05)$. Similarly, in group $C$ there was an increase in pain score at 6 months when compared to that of 4 months as seen in group $\mathrm{M}$ (Table 3 ).

Comparing the VAS score of the two groups (groups $\mathrm{M}$ and $\mathrm{C}$ ) across various time points, there was no statistically significant difference between them (Table 4).

Group C (47.5\%) had lesser side effects compared to group $\mathrm{M}(67.5 \%)$. The most common side effect in medroxyprogesterone acetate group was amenorrhea $(25 \%)$ whereas, in the cabergoline group, it was nausea and vomiting $(45 \%)$ (Table 5).

Table 4 : Comparison of effect of medroxprogesterone acetate (M) and cabergoline (C) on VAS scores at various time points

\begin{tabular}{|c|c|c|c|c|c|c|c|}
\hline & & Mean & $\begin{array}{l}\text { Me- } \\
\text { dian }\end{array}$ & $S D$ & Range & $\begin{array}{l}\text { Mini- } \\
\text { mum }\end{array}$ & $\begin{array}{l}\text { Maxi- } \\
\text { mum }\end{array}$ \\
\hline \multirow{2}{*}{$\begin{array}{l}\text { VAS at } \\
\text { beginning }\end{array}$} & $M$ & $8.93^{*}$ & 9.00 & 0.730 & 2 & 8 & 10 \\
\hline & C & $8.93^{*}$ & 9.00 & 0.730 & 2 & 8 & 10 \\
\hline \multirow{2}{*}{$\begin{array}{l}\text { VAS at } 1 \\
\text { month }\end{array}$} & $M$ & $6.33^{*}$ & 6.00 & 1.023 & 4 & 4 & 8 \\
\hline & C & $5.78^{*}$ & 6.00 & 1.025 & 4 & 4 & 8 \\
\hline \multirow{2}{*}{$\begin{array}{l}\text { VAS at } 3 \\
\text { month }\end{array}$} & $M$ & $4.38^{*}$ & 4.00 & 1.148 & 4 & 3 & 7 \\
\hline & C & $4.30^{*}$ & 4.50 & 1.114 & 4 & 2 & 6 \\
\hline \multirow{2}{*}{$\begin{array}{l}\text { VAS at } 4 \\
\text { month }\end{array}$} & $M$ & $3.53^{*}$ & 4.00 & 0.847 & 3 & 2 & 5 \\
\hline & C & $3.75^{\star}$ & 4.00 & 1.032 & 4 & 2 & 6 \\
\hline \multirow{2}{*}{$\begin{array}{l}\text { VAS at } 6 \\
\text { month }\end{array}$} & $M$ & $4.28^{*}$ & 4.00 & 1.240 & 4 & 2 & 6 \\
\hline & $\mathrm{C}$ & $4.13^{*}$ & 4.00 & 1.137 & 4 & 2 & 6 \\
\hline
\end{tabular}


Table 5 : Comparison of side effect profile between the two groups

\begin{tabular}{llll}
\hline Side effect & $\begin{array}{l}\text { Medroxyprogest- } \\
\text { eroneacetate }\end{array}$ & Cabergoline Total \\
\hline Amenorrhoea & 10 & 0 & 10 \\
Breakthrough bleeding 6 & 1 & 7 \\
Nausea, voimiting & 11 & 18 & 29 \\
Noting significant & 13 & 21 & 34 \\
Total & 40 & 40 & 80 \\
\hline
\end{tabular}

\section{DISCUSSION}

The severity of endometriosis does not determine the degree of symptoms and chronic pelvic pain. Various treatment strategies have been adopted to alleviate the symptoms. In light of limitation associated with conventional treatment, there is an increasing need for developing novel therapeutic agent.

The present study was done to determine the safety and efficacy of cabergoline concerning medroxyprogesterone acetate in decreasing chronic pelvic pain due to endometriosis.

The present study shows that the mean age for endometriosis in the two groups were 29.55 (group M) and 29.65 (group C) which was corroborated by studies conducted by Stacey et al. ${ }^{9}$ and Abbas et al. ${ }^{10}$

This study shows that there was a significant decrease in VAS score in patients receiving Medroxyprogesterone Acetate across various time points.Similar result had been found by Luciano et al., ${ }^{11}$ who showed medroxprogesterone acetate was effective in relieving symptoms and objectively improving endometriosis. Gunning et al. ${ }^{12}$ also had a similar result.

Similarly, in the present study, Cabergoline was found to be very effective in lowering of VAS score in cases of chronic pelvic pain due to endometriosis. Similar results were reported by Hamid et al. ${ }^{13}$ and Ercan et al. (2015) from their studies.

Comparing the effect of the two drugs on VAS score, we have found that there was no statistically significant difference in the pain score of the two groups at 1, 3, 4 and 6 month. The p-value in all cases was $<0.05$. Thus from our study we have found that no one drug is better than the other.

In the present study, patients receiving Cabergoline developed lesser number of side effects than those receiving Medroxyprogesterone Acetate.

Although very limited study is available regarding treatment of endometriosis related chronic pelvic pain, in our study we found that both cabergoline and, medroxyprogesterone acetate are effective in treatment of endometriosis related chronic pelvic pain. Furthermore patients of cabergoline group reported lesser side effects. Compliance with cabergoline is also much better. So cabergoline can be a new and better alternative to conventional medical therapy for endometriosis.

\section{CONCLUSION}

At present there are a number of medical and surgical treatment available for endometriosis, however none of these are effective on long term basis and each treatment modality has its own advantages and disadvantages. Vasculogenesis is an integral part of pathogenesis of endometriosis. Cabergoline inhibits neovasculogenesisand can be a new and better alternative to conventional therapy.

Endometriosis is a chronic disease. Long term investigations are required to elucidate superiority of long term administration of cabergoline compared to the currently available endocrine therapies in terms of decrease of pain, side effect profile and patient satisfaction. Let us give women a pain free today for a better tomorrow.

\section{REFERENCES}

1. Berek and Novak's Gyecology:15 ${ }^{\text {th }}$ edition $2012 ; 506-7$

2. Berek and Novak's Gyecology: $15^{\text {th }}$ edition $2012: 487-88$

3. May K, Becker CM. Endometriosis and angiogenesis. Minerva ginecologica. 2008 Jun;60(3):245-254.

4. McLaren J, Prentice A ,Charnock-Jones DS, Smith SK. Vascular endothelial growth factor (VEGF) concentrations are elevated in peritoneal fluid of women with endometriosis. Hum Reprod 1996 Jan;11:220-223.

5. Donnez J, Smoes P, Gillerot S, Casanas-Roux F, Nisolle M. Vascular endothelial growth factor (VEGF) in endometriosis. Hum Reprod. 1998 Jun;13(6):1686-1690.

6. Basu S, Nagy JA, Pal S, Vasile E, Eckelhoefer IA, Bliss VS, Manseau EJ, Dasgupta PS, Dvorak HF, Mukhopadhyay D. The neurotransmitter dopamine inhibits angiogenesis induced by vascular permeability factor/vascular endothelial growth factor. Nat Med 2001 May;7(5):569-574.

7. Novella-Maestre E, Carda C, Ruiz-Sauri A, Garcia-Velasco JA, Simon $C$ et al. Identification and quantification of dopamine receptor 2 in human entropic and ectopic endometrium; a novel molecular target for endometriosis therapy.Biol Reprod 2010 Nov;83(5):866-873.

8. Novella-Maestre E, Carda C, Noguera I, Ruiz-Sauri A, GarciaVelasco JA, Simon C. Dopamine agonist administration causes a reduction in endometrial implants through modulation of angiogenesis in experimentally induced endometriosis. Hum Reprod. 2009 May;24(5):1025-1035.

9. Missmer SA, Hankinson SE, Spiegelman D, Barbieri RL, Marshall LM, Hunter DJ. Incidence of laparoscopically confirmed endometriosis by demographic, anthropometric and lifestyle factors. Am J Epidemiology.2004 Oct;160(8):784-796

10. Abbas S, Ihle P, Koster I, Schubert I. Prevalence and incidence of diagnosed endometriosis and risk of endometriosis in patients with endometriosis-related symptoms:findings from a statutory health insurance based cohort in Germany. Eur J Obstet Gynecol Reprod Biol. 2012 Jan;160(1):79-83

11. Luciano AA, Turksoy RN, Carleo J. Evaluation of oral medroxyprogesterone acetate in the treatment of endometriosis. Obstet Gynaecol. 1988 Sep;72:323-327

12. Gunning JE, Moyer D. The effect of medroxyprogesterone acetate on endometriosis in the human female. Fertil Steril 1967 Nov-Dec;18:759-774

13. Hamid AM, Madkour WA, Moawad A, Elzaher MA, Roberts MP. Does Cabergoline help in decreasing endometrioma size compared to LHRH agonist?A prospective randomized study. ArchGynaecol Obstet. 2014 March;290(4):677-682. 